\title{
D1 and D2 Dopamine Receptor Function in the Striatum: Coactivation of D1- and D2-Dopamine Receptors on Separate Populations of Neurons Results in Potentiated Immediate Early Gene Response in D1-Containing Neurons
}

\author{
Charles R. Gerfen, ${ }^{1}$ Kristen A. Keefe, ${ }^{1}$ and Estelle B. Gauda ${ }^{1,2}$ \\ 1 Laboratory of Neurophysiology, National Institute of Mental Health, Bethesda, Maryland and ${ }^{2}$ Department of \\ Pediatrics, Johns Hopkins Medical Institutions, Baltimore, Maryland
}

D1- and D2-dopamine receptor-mediated regulation of immediate early gene levels in identified populations of neurons in the striatum was examined with quantitative in situ hybridization histochemical techniques. Levels of messenger RNA (mRNA) encoding the immediate early genes zif268 and c-fos were examined in two experiments in rats with unilateral lesions of the nigrostriatal dopamine pathway. In a dose-response study, animals were treated with doses of $0.5,1.0$, and $1.5 \mathrm{mg} / \mathrm{kg}$ of the D1 agonist SKF38393 either alone or in combination with the D2 agonist quinpirole $(1 \mathrm{mg} / \mathrm{kg}$ ). Levels of immediate early gene mRNAs 60 min following drug treatments showed a doserelated increase to the $\mathrm{D} 1$ agonist alone and a potentiation to combined D1 and D2 agonist treatment. In a second experiment, in animals receiving $1 \mathrm{mg} / \mathrm{kg} \mathrm{SKF-38393}$ either alone or in combination with $1 \mathrm{mg} / \mathrm{kg}$ quinpirole, the level of zif268 mRNA was measured with a double-labeling method in striatal neurons containing enkephalin mRNA, a marker of D2-containing neurons, and in neurons not containing enkephalin, putative D1-containing neurons. In the dopamine-depleted striatum, D1 agonist treatment alone did not affect enkephalin-positive neurons but significantly elevated zif268 mRNA levels in nearly all enkephalin-negative neurons. Combined D1 and D2 agonist treatment further increased zif268 mRNA levels in this population of enkephalin-negative neurons and decreased zit-268 mRNA levels in enkephalin-positive neurons. These data indicate that the synergistic response to combined D1- and D2-receptor stimulation is mediated by interneuronal interactions involving the activation of D1 and D2 receptors on separate populations of striatal neurons.

[Key words: basal ganglia, striatum, dopamine receptor, synergy, gene regulation, immediate early genes, c-fos, zif268, Parkinson's disease]

Dopamine acts within the striatum primarily through two receptors, the D1 and D2 subtypes (Kebabian and Calne, 1979; Levey et al., 1993), which are differentially linked to signal transduc-

Received June 5, 1995; revised Aug. 8, 1995; accepted Aug. 16, 1995.

We thank Ron Paletzki and Dawn Anuskiewicz-Lundgren for their excellent technical support.

Correspondence should be addressed to Charles Gerfen, LNP, NIMH, Building 36, Room 2D-10, Bethesda, MD 20892

Copyright (C) 1995 Society for Neuroscience $0270-6474 / 95 / 158167-10 \$ 05.00 / 0$ tion systems through the GTP-binding proteins Gs and Gi, respectively (Stoof and Kebabian, 1981). In situ hybridization histochemical studies have localized the D1 and D2 receptors to different populations of striatal spiny projection neurons (Gerfen, 1992). The D1 subtype is localized to striatal neurons that project directly to the substantia nigra and contain the neuropeptides dynorphin and substance P (Gerfen et al., 1990; Le Moine et al., 1991), whereas the D2 subtype is localized to striatal neurons that project to the globus pallidus and contain the peptide enkephalin (Gerfen et al., 1990; Le Moine et a1., 1990). Each of these populations of neurons is of roughly equal number and together comprise over $90 \%$ of striatal neurons (Gerfen and Young, 1988; Kawaguchi et al., 1990). Postsynaptic regulation of these striatal neurons through their respective dopamine receptor subtypes has been demonstrated by the selective effects of D1- and D2-selective agonists on peptide levels (Gerfen et al., 1990). Selective activation of striatonigral and striatopallidal neurons through D1 and $\mathrm{D}^{2}$ receptors, respectively, has also been demonstrated by the induction of the immediate early gene protein Fos in striatonigral neurons by acute D1 agonist trcatment in the dopamine-depleted striatum (Robertson et al., 1992) and in striatopallidal neurons by acute $D 2$ antagonist treatment in the intact striatum (Dragunow et al., 1990; Robertson et al., 1992). Together, these data suggest that dopamine acts postsynaptically through D1 and D2 receptors localized to separate populations of striatal neurons (Gerfen, 1992).

Other studies suggest that individual striatal neurons display physiologic responses to both D1 and D2 agonist application and contain mRNAs encoding both D1 and D2 rcceptors (Surmeier et al., 1992). Colocalization of both dopamine receptors is often suggested to account for synergistic responses when both receptors are coactivated (Bertorello et al., 1990; Carlsson and Carlsson, 1990; Piomelli et al., 1991; Paul et al., 1992). D1D2 synergy has been demonstrated by the responses of individual striatal neurons both in vitro (Bertorello et al., 1990) and in vivo (White and Wang, 1986), in the responses of neurons in the globus pallidus and substantia nigra that are affected by striatal projections (Walters et al., 1987; Wcick and Walters, 1987), in behavior (Robertson and Robertson, 1986), and by the induction of the immediate early gene c-fos in striatal neurons (Paul et al., 1992; LaHoste et al., 1993). A question raised by these results is whether the synergistic response occurs in striatal neurons that contain both receptor subtypes. In the present study, the synergistic response to combined D1 and D2 agonist treatments was 
studied in rats with dopamine depletion of the striatum first by analyzing the levels of two immediate early genes, zif268 and c-fos, in a dose-response paradigm examining mRNA levels at the cellular level, and second by examining zif $268 \mathrm{mRNA}$ levels in identified striatal neuron populations in response to D1- and D2-dopamine receptor stimulation.

\section{Materials and Methods}

General experimental design. Male Sprague-Dawley rats were first given unilateral lesions of the nigrostriatal dopamine pathway. Three weeks following the lesions, animals were treated with systemic administration of drugs or vehicle. Drug treatments included a D1-selective agonist ( \pm SKF38393; Research Binchemical Inc., Natick, MA), a D2-selective agonist (quinpirole; Research Biochemical Inc., Natick, MA), or combinations of these drugs. One hour after the drug administration, the rats were killed and their brains prepared for in situ hybridization histochemistry. Brain sections were used for the localization of mRNAs encoding the immediate early genes c-fos and zif268 and enkephalin mRNA, a marker of striatopallidal output meurons. Brain sections were processed for either autoradiographic localization of immediate early gene mRNA levels or combined autoradiographic localization of immediate early gene mRNA and immunohistochemical localization of enkephalin mRNA to identify D2-containing striatal neurons. Following histochemical processing of the sections, the levels of immediate early genes were quantified at the cellular level using image analysis measurement of the number of autoradiographically generated grains over striatal neurons.

Dopamine depletion. Male Sprague-Dawley rats (Taconic, NY) of approximately $200 \mathrm{gm}$ were anesthetized with sodium pentobarbital $(80-90 \mathrm{mg} / \mathrm{kg}$, i.p.) and placed in a stereotaxic instrument. Two microliters of 6-hydroxydopamine-hydrobromide (6-OHDA; $16 \mu \mathrm{g}$, calculated as free base; Sigma Chemical Co., MO) in $0.02 \%$ ascorbic acid $/ 0.9 \% \mathrm{NaCl}$ were infused at a rate of $0.5 \mu 1 /$ rnin into the right medial forebrain bundle/rostral substantia nigra through a 26 gauge needle connected to a $50 \mu \mathrm{l}$ Hamilton syringe on a syringe pump (model 2000, Instech Laboratories, Inc., PA). The cannula was left in place for 3 min after the infusion.

Pharmacological manipulations. Three weeks following unilateral 6-OHDA lesions of the nigrostriatal pathway, animals were treated with dopamine agonists administered systemically. The D1-selective agonist SKF38393 and the D2-selective agonist quinpirole were administered either alone or in combination. Drugs were dissolved in $0.02 \%$ ascorbic acid and administered intraperitoneally in a volume of $1 \mathrm{ml} / \mathrm{kg}$.

In experiment 1 , animals were divided into seven groups of five an imals each. A first group (a, as designated in Table 1) received 0.5 $\mathrm{mg} / \mathrm{kg}$ SKF38393, a second group (b) received $0.5 \mathrm{mg} / \mathrm{kg} \mathrm{SKF38393}$ plus $1.0 \mathrm{mg} / \mathrm{kg}$ quinpirole, a third group (c) received $1.0 \mathrm{~m} \mathrm{~m} / \mathrm{kg}$ SKF38393, a fourth group (d) received $1.0 \mathrm{mg} / \mathrm{kg} \mathrm{SKF} 38393$ plus 1.0 $\mathrm{mg} / \mathrm{kg}$ quinpirole, a fifth group (e) received $1.5 \mathrm{mg} / \mathrm{kg} \mathrm{SKF} 38393$, and a sixth group (f) received $1.5 \mathrm{mg} / \mathrm{kg}$ SKF 38393 plus $1.0 \mathrm{mg} / \mathrm{kg}$ quinpirole. Another group received vehicle injections. Animals were all killed $60 \mathrm{~min}$ after the drug injections. In pilot studies it had been determined that the peak response to both SKF38393 administered alone or in combination with quinpirole, in terms of the elevation of both c-fos and zif $268 \mathrm{mRNA}$ levels, occurred between 60 and $90 \mathrm{~min}$ after drug injection.

In experiment 2 , animals with unilateral 6-OHDA lesions were divided into four groups of five animals each. The first group received vehicle injections and both the unlesioned (a, as listed in Table 2) and lesioned (b) striatum were analyzed, a second group (c) received 1.0 $\mathrm{mg} / \mathrm{kg}$ quinpirole, a third group (d) received $1.0 \mathrm{mg} / \mathrm{kg}$ SKF38393, and a fourth group (e) received $1.0 \mathrm{mg} / \mathrm{kg} \mathrm{SKF} 38393$ plus $1.0 \mathrm{mg} / \mathrm{kg}$ quinpirole. Animals were all killed $60 \mathrm{~min}$ after the drug injections.

In situ hybridization. One hour after drug injections rats were killed with $\mathrm{CO}_{2}$ and decapitated. The brains were rapidly removed and frozen in isopentane chilled on dry ice. Brains were cut in $12 \mu \mathrm{m}$ sections on a cryostat. Sections were thaw-mounted onto gelatin-chrome alumsubbed slides and stored at $-20^{\circ} \mathrm{C}$. Slides for all animals within a given experiment then were postfixed in $4 \%$ formaldehyde $/ 0.9 \% \mathrm{NaCl}$, acetylated in fresh $0.25 \%$ acetic anhydride in $0.1 \mathrm{M}$ triethanolamine $/ 0.9 \%$ $\mathrm{NaCl}$, dehydrated in an ascending series of alcohols, delipidated in chloroform, and then rehydrated in a descending series of alcohols. Slides were air dried and then stored at $-20^{\circ} \mathrm{C}$.

In experiment 1 , for detection of zif 268 and c-fos mRNAs, 48-base oligonucleotide probes complementary to bases 352-399 for zif268 (Milbrandt, 1987) and 1227-1274 for c-fos (Curran et al., 1987), respectively, were synthesized on an Applied Biosystems DNA synthesizer. For the determination of tyrosine hydroxylase (TH) mRNA, a 48base oligonucleotide probe complementary to bases 1441-1488 of the rat TH gene was made. Purified probes were end-labeled with ${ }^{35} \mathrm{~S}$-dATP and terminal deoxynucleotidyl transferase (Boehringer Mannheim, IN), and diluted in hybridization buffer to obtain $2 \times 10^{6} \mathrm{cpm} / 100 \mu \mathrm{l}$. The hybridization buffer contained $0.6 \mathrm{M} \mathrm{NaCl}, 80.0 \mathrm{~mm}$ Tris ( $\mathrm{pH} 7.5), 4.0$ mM EDTA, $0.1 \%(\mathrm{wt} / \mathrm{vol})$ sodium pyrophosphate, $10 \%(\mathrm{wt} / \mathrm{vol})$ dextran sulfate, $0.2 \%(\mathrm{wt} / \mathrm{vol})$ sodium decodyl sulfate, $0.02 \%(\mathrm{wt} / \mathrm{vol})$ heparin sulfate, $50 \%$ (vol $/ \mathrm{vol}$ ) formamide, and $100 \mathrm{~mm}$ dithiothreitol. Ninety microliters of hybridization buffer with probe were applied to each slide containing three to four sections and covered with a glass coverslip.

Slides were hybridized for $12-18 \mathrm{hr}$ in humid chambers at $37^{\circ} \mathrm{C}$. Upon removal, slides were washed four times in $1 \times \operatorname{SSC}(0.15 \mathrm{M}$ $\mathrm{NaCl} / 0.015 \mathrm{M}$ sodium citrate, $\mathrm{pH} 7.2$ ) at room temperature and then three times for $20 \mathrm{~min}$ each in $2 \times \mathrm{SSC}$ with $50 \%$ ( $\mathrm{vol} / \mathrm{vol}$ ) formamide at $40^{\circ} \mathrm{C}$. Finally, slides were washed $2 \times 30 \mathrm{~min}$ in $1 \times \mathrm{SSC}$ at room temperature, dipped in deionized water, and air dried. Labeled slides were dipped in Kodak emulsion diluted 1:1 with water and $0.1 \%$ Dreft detergent and stored frozen for 4-8 weeks. Slides were then thawed and developed with Dektol $\left(1: 1\right.$ with water, 2 min at $17^{\circ} \mathrm{C}$ ), stopped for 1 min with $0.5 \%$ acetic acid, fixed for 2 min with Rapid Fix without hardener (Kodak), rinsed for $30 \mathrm{~min}$ in water, stained with thionin, dehydrated, and covcrslipped with Permount from xylene.

In experiment 2, sections were double labeled with ribonucleotide antisense probes to determine the colocalization of zif 268 and enkephalin mRNAs. A plasmid containing enkephalin cDNA (450 nucleotides; Yoshikawa et al, 1984) was linearized with EcoR1 and an antisense ribonucleotide probe was generated with UTP coupled to digoxigenin using SP6 polymerase. A plasmid containing zif268 cDNA $(3100 \mathrm{nu}-$ cleotides; Milbrandt, 1987) was linearized with Hind3 and an antisense ribonucleotide probe was generated with ${ }^{35} \mathrm{~S}$-UTP using T7 polymerase. Four microliters of zif 268 riboprobe $\left(1 \times 10^{6} \mathrm{cpm}\right)$ and $4 \mu \mathrm{l}$ of enkephalin digoxigenin-labeled probe were added to each $100 \mu \mathrm{l}$ of hybridization buffer $(50 \%$ formamide, $600 \mathrm{~mm} \mathrm{NaCl}, 80 \mathrm{~mm}$ Tris $\mathrm{HCl}$, pH 7.5, $4 \mathrm{~mm}$ EDTA, $0.1 \%$ sodium pyrophosphate, $0.2 \%$ SDS, $2 \%$ sodium polyacrylate, $100 \mathrm{~mm}$ dithiothreitol; $1 \mu \mathrm{g}$ tRNA; $1 \mu \mathrm{g}$ total RNA; $0.4 \mu \mathrm{g}$ salinon sperm DNA) and applied to slides containing three to four brain sections prepared as above for oligonucleotide probe labeling. Hybridization was carried out at $55^{\circ} \mathrm{C}$ for $12 \mathrm{hr}$, after which the hybridization buffer was rinsed off sections in $1 \times \mathrm{SSC}$ at room temperature. After treatment with RNase A $(20 \mathrm{mg} / \mathrm{ml})$ for 30 min, slides were then washed for $4 \times 20 \mathrm{~min}$ at $65^{\circ} \mathrm{C}$ in $0.2 \times \mathrm{SSC}$, rinsed in Tris $(0.5 \mathrm{M}, \mathrm{pH} 7.5)$ saline $(0.9 \%)$ at room temperature for $5 \mathrm{~min}$, and incubated in Tris-buffered saline with $3 \%$ normal goat serum, $0.3 \%$ Triton $\mathrm{X}-100$, and rabbit IgG directed against digoxigenin coupled to alkaline phosphatase (1:1000) for $4 \mathrm{hr}$. Sections were then rinsed three times in Tris-buffered saline for $10 \mathrm{~min}$ each and placed in a buffer containing $100 \mathrm{~mm}$ Tris IICl, $100 \mathrm{~mm} \mathrm{NaCl}, 50 \mathrm{~mm} \mathrm{MgCl}, \mathrm{pH} 9.5$, together with nitroblue tetrazolium salt $(0.34 \mathrm{mg} / \mathrm{ml})$ and 5 -bromo-4-chloro-3-indolyl phosphate toluidinium salt (NBT/BCIP; $0.18 \mathrm{mg} / \mathrm{ml}$; Boehringer Mannheim) for $12-18 \mathrm{hr}$ to generate an alkaline phosphatase immunohistochemical reaction product to localize digoxigenin-labeled probes. The alkaline phosphatase reaction was stopped by placing the sections in the reaction buffer plus $1.0 \mathrm{M}$ EDTA for $30 \mathrm{~min}$, after which the sections were rinsed in water and air dried. Slide mounted sections thus processed were then dipped in Amersham photographic emulsion, dried, and allowed to expose in the dark $\left(\right.$ at $\left.-20^{\circ} \mathrm{C}\right)$ for $4-6$ weeks. Slides were then thawed and developed with Dektol $(1: 1$ with water, 2 min at $17^{\circ} \mathrm{C}$ ), stopped for $1 \mathrm{~min}$ with $0.5 \%$ acetic acid, fixed for $2 \mathrm{~min}$ with Rapid Fix without hardener (Kodak), rinsed for $30 \mathrm{~min}$ in water, dehydrated, and coverslipped with Permount from xylene.

Data analysis. An area of identical size from the dorsal striatum was selected from each brain section for analysis, containing approximately 250-300 neurons. A montage of images from the selected area, digitized at $400 \times$ through a Leitz microscope, was stored in a Macintosh image analysis program (NIH IMAGE, W. Rasband, NIMH). Grains were measured using a peak-counting algorithm. In experiment 1 , in which sections were counterstained with thionin, each cell in the digitized images was analyzed for the number of autoradiographic grains in a fixed area with a diameter of $40 \mu \mathrm{m}$ centered on neurons, which averaged $25 \mu \mathrm{m}$ in diameter. In experiment 2 , zif $268 \mathrm{mRNA}$, localized by the generation of autoradiographic silver grains, and enkephalin mRNA, localized by 
immunohistochemical generation of a blue alkaline phosphatase reaction product, were labeled in the same brain sections. A similar image analysis method was used as for experiment 1, except that grains over enkephalin-positive neurons and grains over cells that were enkephalinnegative were counted separately. In both experiments, data were analyzed as a distribution of the number of cells displaying grain counts in bins of five grains per cell. Thus, for each animal the number of cclls with $0-5,6-10,11-15$, etc., grains were tabulated as a frequency distribution. For the c-fos mRNA-labeled sections grains over all cells were counted. The majority of cells showed very low numbers of grains. The cutoff for determining the number of labeled cells was determined by an inspection of the frequency distribution of grains per cell and assuming a normal distribution. For zif $268 \mathrm{mRNA}$-labeled sections, all counted cells were considered to have some amount of label. The data for each group were averaged and compared to determine statistically the difference between groups in terms of both the numbers of labeled cells and the average grains per cell using a two-way analysis of variance and post hoc $t$ tests with the Bonferroni correction. Statistical significance was set at $p<0.05$.

\section{Results}

\section{Efficacy of 6-OHDA lesions}

The efficacy of the lesions was determined by the depletion of greater than $90 \%$ of neurons expressing tyrosine hydroxylase mRNA in the substantia nigra on the lesioned side and/or the elevation of enkephalin mRNA to greater than $150 \%$ in the dopamine-depleted striatum compared to the intact side (Gerfen et al., 1991). All animals used in these experiments met this criteria.

\section{Dose-response effects of DI and D2 agonist treatments on striatal c-fos $m R N A$ levels}

In the first experiment, the level of expression of the immediate early gene mRNAs encoding c-fos and zif268 was examined at the cellular level in the dopamine-depleted striatum of animals receiving single injections of different doses of the Dl agonist SKF38393 $(0.5,1.0$, and $1.5 \mathrm{mg} / \mathrm{kg})$ alone or in combination with the D2 agonist quinpirole $(1 \mathrm{mg} / \mathrm{kg})$.

In both the unlesioned and dopamine-depleted striatum of animals receiving vehicle injections, few neurons show detectable levels of c-fos mRNA. Figure 1 shows examples of c-fos mRNA in the striatum of animals treated with different doses of D1 agonist alone and in combination with D2 agonist treatment. Figure $3 A-C$ shows the frequency distribution of neurons expressing different levels of c-fos mRNA measured as the number of grains per labeled cell. Table 1 shows the average number of cells with detectable levels of label and the average number of grains per cell for each treatment group. Results indicate that there is a dose-dependent increase in the number of cells expressing c-fos to SKF-38393 treatment alone, in that the number of labeled cells is significantly greater at a dose of $1.5 \mathrm{mg} / \mathrm{kg}$ as compared to either 0.5 or $1.0 \mathrm{mg} / \mathrm{kg}$. Additionally, there is a significant increase in the numbers of neurons labeled for each dose of SKF-38393 combined with quinpirole compared with that obtained with the D1 agonist alone, indicative of a synergistic response.

\section{Dose-response effects of $D 1$ and $D 2$ agonist treatments on} striatal zif $268 \mathrm{mRNA}$ levels

Figure 2 shows examples of zif268 labeled neurons in the striatum of rats treated with different doses of D1 agonist alone and in combination with D2 agonist treatment. The frequency distribution of neurons showing different levels of zif 268 mRNA labeling for the different doses is shown in Figure $3 D-F$. Initially, zif268 labeling was determined for all neurons in the analysis area. However, two distinct populations of neurons were identified, particularly in the treatment groups receiving 1.0 and $1.5 \mathrm{mg} / \mathrm{kg}$ SKF38393. For analysis, these two populations were separated, assuming a normal distribution for each, into one showing a relatively low level of labeling and one showing a relatively high level of labeling. Using this method of analysis, it can be seen that these two populations of neurons are of roughly equal size (Table 1 ). In response to D1 agonist alone, there is a dose dependent increase in the amount of labeling (grains/cell) in the population showing high zif268 levels comparing the 0.5 and $1.0 \mathrm{mg} / \mathrm{kg}$ doses. Combined treatment with D1 and D2 agonists results in a further increase in the amount of labeling in this population expressing high zif268 levels. In the groups receiving the two highest doses of D1 agonist, combined D1 and D2 agonist treatment results in the number of grains per cell being decreased in the population that shows lower levels of labeling. In neither population does the combined treatment with D1 and D2 agonists alter the number of neurons expressing zif $268 \mathrm{mRNA}$ over the effects of D1 agonist treatment alone (Table 1).

\section{Effects of D1 and D2 agonist treatments on zif $268 \mathrm{mRNA}$ levels in identified striatal neurons}

Figure 4 shows examples of double labeling for zif268 mRNA and enkephalin mRNAs. Enkephalin mRNA was used to identify putative D2 receptor-containing neurons in the intact and dopamine-depleted striatum of animals receiving vehicle injections, and in the dopamine-depleted striatum of animals receiving a single treatment of the D1 agonist SKF38393 (1 $\mathrm{mg} / \mathrm{kg}$ ) alone or in combination with the D2 agonist quinpirole (1 $\mathrm{mg} / \mathrm{kg}$ ). In the unlesioned striatum, there is a relatively low lcvel of zif 268 mRNA labeling in both enkephalin-positive and enkephalin-negative neurons, with the latter showing a slightly higher level of expression. In the dopamine-depleted striatum, there is a significant increase in the number of labeled neurons and in the amount of zif $268 \mathrm{mRNA}$ (grains/cell) in enkephalinpositive neurons, and a significant decrease in both the number of labeled enkephalin-negative neurons and the amount of label per cell, compared to the unlesioned striatum. In the dopaminedepleted striatum of animals treated with quinpirole alone compared to the dopamine-depleted striatum of vehicle-injected animals, there is a significant decrease in the number of enkephalin-positive neurons displaying zif268 mRNA labeling and in the average label per cell, whereas there is no significant difference in enkephalin-negative neurons in either the number labeled or the average label per cell. Administration of SKF38393 (1 mg/kg) significantly increased both the number of enkephalin negative cells labeled for zif268 mRNA and the average number of grains over these cells. In animals treated with the D1 agonist SKF38393 (1 mg/ $\mathrm{kg})$ plus the D2 agonist quinpirole ( $1 \mathrm{mg} / \mathrm{kg})$, enkephalin-positive cells showed a significant decrease in the amount of label per cell, whereas enkephalin-negative cells showed a significant increase in the amount of label per cell, relative to animals receiving SKF38393 (1 mg/kg) alone. Combined treatment with the D1 and D2 agonists did not change the number of enkephalinnegative or enkephalin-positive cells labeled for zif268.

In addition, we examined the globus pallidus for the expression of zif 268 mRNA labeling in these animals. In the globus pallidus of animals receiving vehicle injections there were few neurons expressing zif268 mRNA on either the lesioned or unlesioned side. Injections of SKF38393 (1 Ing/kg) produced little change in the number of neurons showing zif2 $68 \mathrm{mRNA}$ label- 

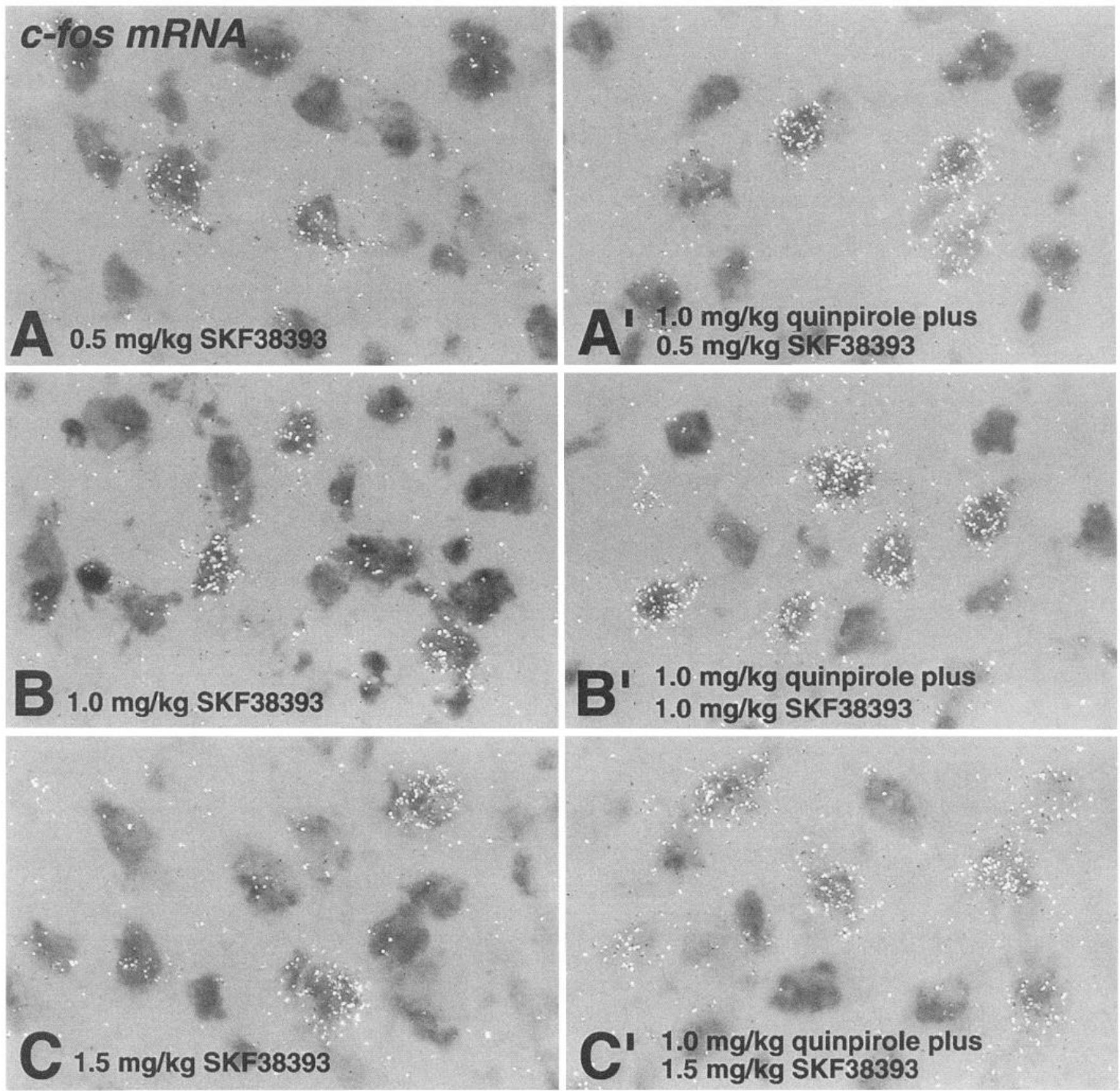

Figure 1. Photomicrographs of in situ hybridization histochemical localization of c-fos mRNA labeling in sections of the striatum. Images are from the dopamine-depleted striatum of animals treated with the D1 agonist SKF38393 alone at doses of $0.5(A), 1.0(B)$, and $1.5(C) \mathrm{mg} / \mathrm{kg}$ or at these doses of D1 agonist treatment combined with the D2 agonist quinpirole at a dose of $1.0 \mathrm{mg} / \mathrm{kg}\left(A^{\prime}-C^{\prime}\right)$. Grains over thionin-labeled cells are generated by the autoradiographic localization of ${ }^{35} \mathrm{~S}$-labeled cfos mRNA and appear as white dots. Magnification, $400 \times$.

ing on either side. In animals receiving injections of SKF38393 plus quinpirole, and in animals receiving quinpirole alone, there were many neurons in the globus pallidus displaying zif268 mRNA labeling (data not shown), comparable to previous reports (Paul et al., 1992; Marshall et al., 1993; LaHoste and Marshall, 1994).

\section{Discussion}

The present results demonstrate a dose-dependent increase in immediate early gene induction in D1 receptor-containing neurons in response to D1 receptor agonist treatment. In addition, we report a potentiated increase in immediate early gene levels in this same population of D1 receptor-containing neurons to combined D1 and D2 receptor agonist treatment that is correlated with a decrease in immediate early gene levels in D2 receptor-containing neurons. These results indicate that dopamine function in the striatum, as measured by altered gene regulation, is mediated by the segregated distribution of D1 and D2 receptor subtypes on different populations of striatal neurons. Additionally, these data suggest that the potentiation of immediate early gene induction in D1 receptor-containing neurons may be due 

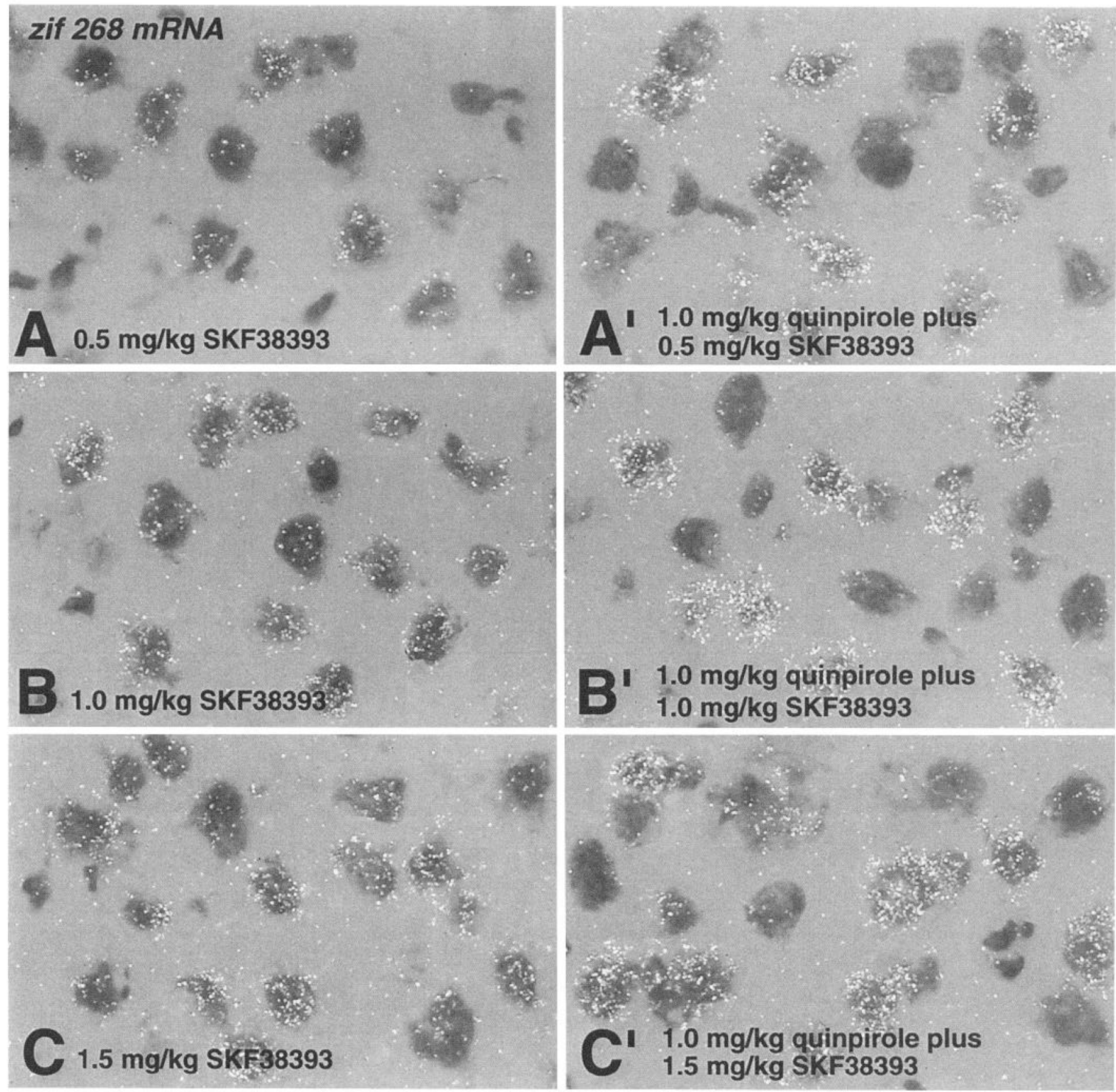

Figure 2. Photomicrographs of in situ hybridization histochemical localization of zif $268 \mathrm{mRNA}$ labeling in sections of the striatum. Images are from the dopamine-depleted striatum of animals treated with the D1 agonist SKF38393 alone at doses of $0.5(A), 1.0(B)$, and $1.5(C) \mathrm{mg} / \mathrm{kg}$ or at these doses of D1 agonist treatment combined with the D2 agonist quinpirole at a dose of $1.0 \mathrm{mg} / \mathrm{kg}\left(A^{\prime}-C^{\prime}\right)$. Grains over thionin-labeled cells are generated by the autoradiographic localization of ${ }^{35} \mathrm{~S}$-labeled zif $268 \mathrm{mRNA}$ and appear as white dots. Magnification, $400 \times$.

to a decreased inhibition of D1 receptor-containing neurons by D2 receptor-containing neurons.

\section{Technical considerations}

One of the objectives of the present studies was to determine the striatal neuron populations in which dopamine receptor-mediated immediate early gene induction occurs. In experiment 1 , there appeared to be two distinct neuron populations displaying immediate early gene responses: one with low levels of zif 268 mRNA and one with high levels, which were differently affected by D1 and D2 agonist treatment. In experiment 2, striatal efferent neuron populations were identified by the localization of enkephalin mRNA. Enkephalin has been demonstrated to be a reliable marker of striatopallidal neurons (Gerfen and Young, 1988), which have also been demonstrated to express D2 receptor mRNA (Gerfen et al., 1990). Moreover, studies in which enkephalin and D2 mRNAs have been examined together in intact histologic sections have reported nearly complete colocalization of these mRNAs, and absence of D2 mRNA with markers that are coexpressed with D1 mRNA (Le Moine et al., 1990). 

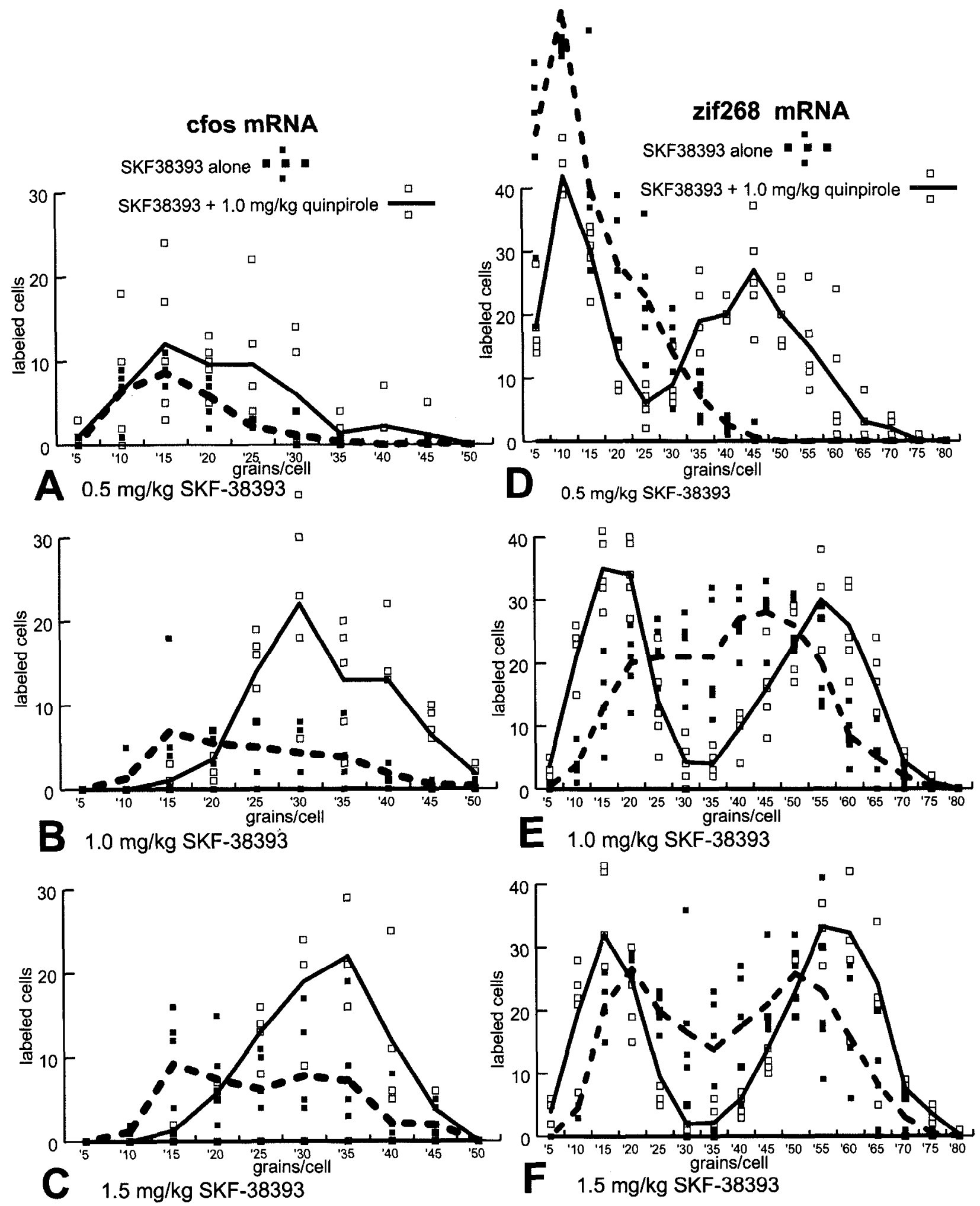

Figure 3. Frequency distribution displaying the amount of label (average grains per cell) in cells from experiment 1 showing amount of c-fos mRNA $(A-C)$ and zif268 mRNA $(D-F)$ labeling from the same sets of animals. In each graph data are provided for doses of SKF38393 administered alone (average shown as a broken gray line, data from individual cases shown as gray squares), and together with $1 \mathrm{mg} / \mathrm{kg}$ quinpirole (average shown as a solid black line, individual cases shown as white squares).

Identification of the neuronal population showing induction of DI-mediated immediate early genes

The induction of immediate early genes, in particular c-fos (Morgan and Curran, 1989), has been repeatedly used as a mark- er of acute dopamine receptor-mediated regulation of striatal neurons (Robertson et al., 1989, 1992; Dragunow et al., 1990; Graybiel et al., 1990; Young et al., 1991; Berretta et al., 1992; Cenci et al., 1992; Paul et al., 1992; Steiner and Gerfen, 1993, 
Table 1. Experiment 1

\begin{tabular}{lllllllll} 
& \multicolumn{9}{c}{ Treatment group } \\
\cline { 3 - 8 } & & $\mathrm{a}$ & $\mathrm{b}$ & $\mathrm{c}$ & $\mathrm{d}$ & $\mathrm{e}$ & $\mathrm{f}$ \\
\hline Treatment & SKF38393 & 0.5 & 0.5 & 1 & 1 & 1.5 & 1.5 \\
\hline $\mathrm{mg} / \mathrm{kg})$ & Quinpirole & 0 & 1 & 0 & 1 & 0 & 1 \\
\hline c-fos mRNA & Labeled cells & 25.0 & $49.2^{+\mathrm{a}}$ & 23.2 & $75.6^{+\mathrm{c}}$ & $43.2^{+\mathrm{a}, \mathrm{c}}$ & $76.3^{+\mathrm{e}}$ \\
& Grains/cell & 17.0 & 21.2 & 24.6 & 32.1 & 24.1 & 31.9 \\
zif mRNA & & & & & & & \\
High-level cells & Labeled cells & 110.4 & 115.2 & 133.8 & 128.2 & 122.6 & 124.8 \\
& Grains/cell & 24.0 & $44.8^{+\mathrm{a}}$ & $41.5^{+\mathrm{a}}$ & $54.0^{+\mathrm{c}}$ & $43.8^{+\mathrm{a}, \mathrm{c}}$ & $55.3^{+\mathrm{c}}$ \\
Low-level cells & Labeled cells & 120.2 & 115.4 & 120.8 & 118.8 & 98.2 & 93.0 \\
& Grains/cell & 10.0 & 10.9 & 24.6 & $17.2^{-\mathrm{c}}$ & 21.0 & $15.9^{-\mathrm{e}}$
\end{tabular}

Data were derived from that shown graphically in Figurc 3 of the average number of cells with detectable levels of label and the average number of grains per cell for each treatment group ( $N=5$ for each group). Treatment groups are described in the top two rows of each column, listing the amount (in $\mathrm{mg} / \mathrm{kg}$ ) of drugs administered. All measurements are those from the dopamine-depleted striatum. Treatment group letters are used to designate which relevant statistical comparisons show significant changes. Dose-dependent changes are seen in the increased number of labeled c-fos cells in the group receiving $1.5 \mathrm{mg} / \mathrm{kg}$ SKF38393 (e) compared with those receiving 0.5 and 1.0 $\mathrm{mg} / \mathrm{kg}$ SKF38393 (a,c) and in the number of zif $268 \mathrm{mRNA}$ grains per cell for the groups receiving either 1.0 (c) or 1.5 (e) $\mathrm{mg} / \mathrm{kg} \mathrm{SKF38393} \mathrm{compared} \mathrm{with} \mathrm{the} \mathrm{group} \mathrm{receiving} 0.5 \mathrm{mg} / \mathrm{kg}$ (a). Synergistic responses to combined SKF38393 and quinpirole treatments are evident in the increased number of c-fos-labeled cells for each dose group and in the increased number of zif $268 \mathrm{mRNA}$ grains per cell for each dose group. This latter synergistic response is correlated with a decreased number of zif268 mRNA grains per cell in the cells with low-level labeling for treatment groups receiving 1.0 and $1.5 \mathrm{mg} / \mathrm{kg}(-\mathrm{c},-\mathrm{e})$. Statistical analysis was done with a two-way analysis of variance and post hoc $t$ tests with the Bonferroni correction, $p<0.05$. $+x$, significant increase relative to column $x, p<0.05 ;-x$, significant decrease relative to column $x, p<0.05$.

1994; LaHoste and Marshall, 1994; Keefe and Gerfen, 1995). In prior studies of D1 and D2 synergy, doses of D1 agonist that by themselves showed little c-fos induction, when combined with D2 agonist treatment showed an increased number of neurons with detectable c-fos immunoreactivity (Paul et al., 1992). The present data provide similar results using in situ hybridization to detect c-fos mRNA. From such results it has been concluded that stimulation of both D1 and D2 receptors is necessary for most neurons to achieve the threshold response required for induction of both c-fos mRNA and c-fos protein (Paul et al., 1992; LaHoste et al., 1993). However, a limitation of such a conclusion is that $\mathrm{c}$-fos levels provide a measure of a threshold response but do not provide a measure of a graded response in individual cells.

Using c-fos as a marker of striatal neuron response to dopamine agonist treatment, it might also be concluded that only a subpopulation of D1 receptor-containing neurons are responsive to D1 agonist treatment alone. The effects of such manipulations on another immediate early gene, zif 268 , suggest that this is not the case. The present results using this immediate early gene marker show that D1 agonist treatment alone results in induction in approximately the same number of neurons as occurs from combined D1 and D2 agonist treatment. This result is apparent in the data from both the dose-response experiment and from the double-labeling experiment.

The double-labeling experiment in the present study enables the identification of the two populations of neurons that show responses to dopamine receptor agonist treatments. In this experiment, the level of labeling in the unlesioned and lesioned striatum of animals treated with vehicle provides an instructive baseline. In the unlesioned striatum, there is a low level of labeling in enkephalin-containing neurons and a slightly higher level of labeling in non-enkephalin neurons. Dopamine depletion results in a reversal of this pattern, with the enkephalin-containing population of neurons showing increased zif268 labeling, and the non-enkephalin-containing population showing a de- creased level of labeling. This effect of dopamine depletion on the level of zif 268 expression in these two populations of striatal neurons corresponds with the altered levels of peptides seen in these two populations of striatal neurons after dopamine-depleting lesions (Gerfen et al., 1990, 1991). Thus, activation of D2 receptors appears to decrease gene markers in striatopallidal neurons and activation of D1 receptors appears to increase gene markers in striatonigral neurons.

D1 agonist treatment alone resulted in increased zif268 levels in enkephalin-negative neurons. D1 plus D2 agonist treatment results in a further increase in zif $268 \mathrm{mRNA}$ levels in enkephalin-negative neurons, coupled with a decrease in the level of labeling in enkephalin-positive neurons. Taken together, these data demonstrate that induction of immediate early genes occurs in the same population of neurons when the D1 agonist is given alone or in combination with a D2 agonist and that this population is the enkephalin-negative, D1 receptor-containing, striatonigral neurons (Gerfen et al., 1990).

\section{Possible mechanisms of D1-D2 receptor synergy}

Prior studies of D1 D2 receptor synergy have suggested mech anisms involving colocalization of receptors in the same neuron population (Bertorello et al., 1990; Carlsson and Carlsson, 1990; Piomelli et al., 1991; Paul et al., 1992), which are supported by the findings of colocalization of D1 and D2 mRNAs in striatal neurons (Surmeier et al., 1992). However, localization studies of dopamine receptors using in situ hybridization localization of mRNAs (Gerfen et al., 1990; Le Moine et al., 1990, 1991) and immunohistochemical localization of receptor proteins (Levey et al., 1993; Hersch et al., 1995) demonstrate D1 and D2 receptor subtypes in separate populations of neurons. The present data, in which the expression of zif268 mRNA is selectively and oppositely affected, respectively, in enkephalin-positive and enkephalin-negative neurons by D2 and D1 receptor agonist administration alone, support the segregation of these receptor subtypes to separate striatal neuron populations. Therefore, we pro- 

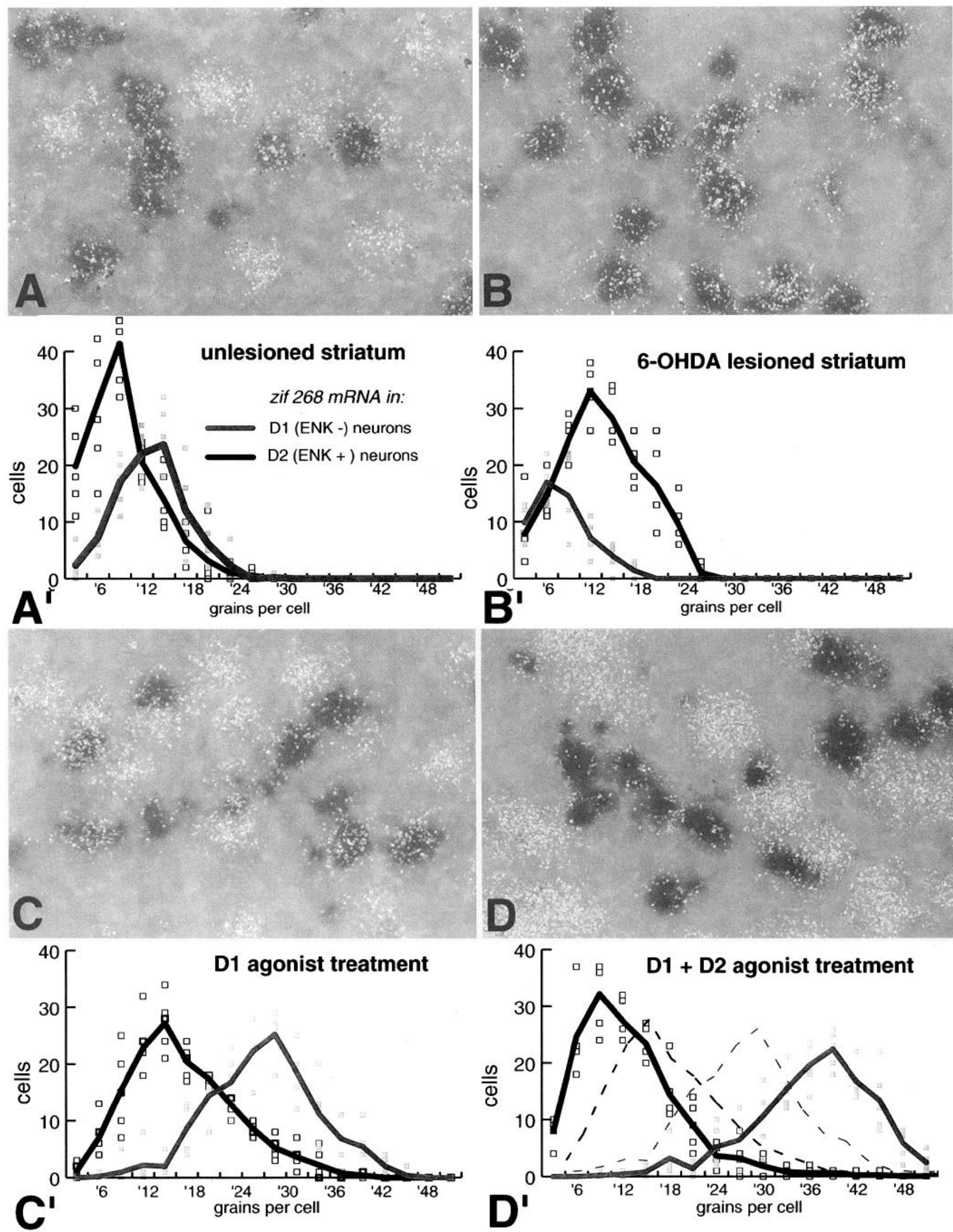
Table 2. Experiment 2

\begin{tabular}{|c|c|c|c|c|c|c|}
\hline & & Treatmer & nt group & & & \\
\hline & & a & $\mathrm{b}$ & c & d & $\mathrm{e}$ \\
\hline Treatment & $\begin{array}{l}\text { Lesion } \\
\text { SKF38393 } \\
\text { Quinpirole }\end{array}$ & $\begin{array}{l}\text { Control } \\
0 \\
0\end{array}$ & $\begin{array}{l}6-\mathrm{OHDA} \\
0 \\
0\end{array}$ & $\begin{array}{l}\text { 6-OHDA } \\
0 \\
1\end{array}$ & $\begin{array}{l}\text { 6-OHDA } \\
1 \\
0\end{array}$ & $\begin{array}{l}\text { 6-OHDA } \\
1 \\
1\end{array}$ \\
\hline Enkephalin-positive cells & zif-labeled cells & 121.0 & $143.6^{+a}$ & $123.0^{-b}$ & 137.0 & 140.0 \\
\hline & Grains/cell & 9.5 & $13.6^{+a}$ & $8.0^{-\mathrm{h}}$ & $17.6^{+c}$ & $12.7^{-d}$ \\
\hline Enkephalin-negative cells & $\begin{array}{l}\text { zif-labeled cells } \\
\text { Grains/cell }\end{array}$ & $\begin{array}{r}113.4 \\
13.1\end{array}$ & $\begin{array}{r}54.0^{-\mathrm{a}} \\
7.9^{-\mathrm{a}}\end{array}$ & $\begin{array}{r}58.8 \\
9.0\end{array}$ & $\begin{array}{r}131.0^{\mathrm{b}, \mathrm{c}} \\
27.6^{+\mathrm{h}, \mathrm{c}}\end{array}$ & $\begin{array}{l}134.0 \\
37.1^{+d}\end{array}$ \\
\hline
\end{tabular}

Data were derived from that shown graphically in Figure 4 of the average number of cells with detectable levels of zif268 (zif) mRNA label and the average number of grains per cell for each treatment group ( $N=5$ for each group). Treatment groups are described for each column, lising the amount (in $\mathrm{mg} / \mathrm{kg}$ ) of drugs administered. The population of cells described are designated below. Treatment group lellers are used to designate which statistical comparisons show a significant change. Note that comparisons between the group receiving SKF38393 alone (d) compared to that receiving both SKF38393 and quinpirole (e) show that in the enkaphalin-positive cells there is a significant decrease (-) in the number of zif268 mRNA grains per cell while in the enkaphalin-negative cells there is a significant increase $(+)$. Statistical analysis was done with a two-way analysis of variance and post hoc $t$ tests with the Bonferroni correction, $p<0.05$. $+x$, significant increase relative to column $x, p<0.05 ;-x$, significant decrease relative to column $x, p<0.05$.

pose that the potentiated response of striatonigral neurons to combined D1 and D2 agonist treatment reflects an interneuronal interaction between D2- and D1-containing neurons.

Striatal spiny neurons, which are the neurons in question, have axon collaterals within the local area of their cell bodies that make synaptic contact with neighboring spiny neurons (Wilson and Groves, 1980). Immunohistochemical data suggest that D1and D2-containing neurons are in fact interconnected (Hersch et al., 1995). Electron microscopic ultrastructural localization of peptides such as substance $P$ and enkephalin, which are markers of D1 and D2 neurons, respectively, have demonstrated contacts between these different neuron types (Bolam and Izzo, 1988). Thus, there appear to exist synaptic contacts between D2- and D1-containing neurons.

Based on our present results, we propose that the potentiated response of D1-containing neurons to combined D1 and D2 agonist treatment results from reduction of an inhibitory influence of D2-containing neurons on D1-containing neurons as a consequence of D2 agonist-mediated inhibition of D2 receptor-containing neurons. D2 agonist treatment, either alone or in combination with D1 agonist treatment, results in decreased expression of zif268 in enkephalin neurons, which also express the D2 dopamine receptor. Several lines of evidence are consistent with an inhibitory effect through D2 receptors. Dopamine depletion results in increased enkephalin mRNA in D2-containing neurons, which is reversed with D2 agonist treatment (Gerfen et al., 1990), and D2 antagonist treatments result in the induction of c-fos in striatopallidal, D2-containing neurons (Dragunow et al., 1990; Robertson et al., 1992). Evidence that D2-mediated inhibition of striatopallidal neurons results in decreased inhibition of their targets comes from the present report that D2 agonist treatment results in the induction of immediate early genes in neurons in the globus pallidus, confirming earlier reports (Paul et al., 1992; Marshall et al., 1993; LaHoste and Marshall, 1994).
Physiologic studies have failed to detect an inhibitory effect between striatal medium spiny neurons (Jaeger et al., 1994). This raises the possibility that the present demonstrated decrease in the function of D2-containing neurons that is correlated with a potentiated D1 response is merely a correlation and involves other mechanisms. Among those possible are indirect connections between D2- and D1-containing striatal neurons involving striatal intcrncurons. For cxamplc, cholincrgic striatal neurons also contain the D2 dopamine receptor and might be involved in the mediation of D1-D2 synergy (Le Moine et al., 1990). Other striatal interneuron populations, including somatostatin or GABAergic interneurons, might also be involved. Finally, although there may not be a direct physiologic inhibitory response between striatal spiny neurons, there may still be synaptically mediated interactions between these neurons that do not produce acute changes in membrane potential.

\section{Conclusions}

The present results demonstrate that in the dopamine-depleted striatum D1 agonist treatment alone results in a response in the majority of D1 receptor-containing striatal neurons, and combined D1 and D2 agonist treatment results in a potentiated response in this same population of Dl-containing neurons, coupled with a decrease in response in D2-containing neurons. These data indicate that the synergistic response to combined D1 - and D2-receptor stimulation is mediated by interneuronal interactions involving the activation of D1 and D2 receptors on separate populations of striatal neurons.

\section{References}

Berretta S, Robertson HA, Graybiel AM (1992) Dopamine and glutamate agonists stimulate neuron-specific expression of Fos-like protein in the striatum. J Neurophysiol 68:767-777.

Bertorello AM, Hopfield JF, Aperia A, Greengard P (1990) Inhibition by dopamine of $\left(\mathrm{Na}^{+}+\mathrm{K}^{+}\right)$ATPase activity in neostriatal neurons

$\leftarrow$

Figure 4. Photomicrographs and frequency distribution of the amount of zif $268 \mathrm{mRNA}$ labeling in the striatum of animals in experiment 2 . Photomicrographs $(A-D)$ show zif268 mRNA labeling $\left({ }^{35} \mathrm{~S}\right.$-generated silver grains, white) in sections labeled for enkephalin mRNA (dark cells labeled with alkaline phosphatase reaction product). Frequency distribution graphs $\left(A^{\prime}-D^{\prime}\right)$ provide data of the average amount of zif268 mRNA label per cell for enkephalin-positive cells, which are putative D2-containing neurons (ENK + , individual cases marked as white squares, average marked as a black line), and enkephalin-negative, putative D1-containing cells (ENK-, individual cases marked as gray squares, average marked as a gray line). Quantitative data are provided in Table 2. 
through $\mathrm{D}_{1}$ and $\mathrm{D}_{2}$ dopamine receptor synergism. Nature 347:386388.

Bolam JP, Izzo PN (1988) The postsynaptic targets of substance P-immunoreactive terminals in the rat neostriatum with particular reference to identified spiny striatonigral neurons. Exp Brain Res 70:361377.

Carlsson M, Carlsson A (1990) Interactions between glutamatergic and monoaminergic systems within the basal ganglia-implications for schizophrenia and Parkinson's disease. Trends Neurosci 13:272-276.

Cenci MA, Campbell K, Wictorin K, Björklund A (1992) Striatal $c$ fos induction by cocaine or apomorphine occurs preferentially in output neurons projecting to the substantia nigra in the rat. Eur J Neu rosci 4:376-380.

Curran T, Gordon MB, Rubino KL, Sambucetti LC (1987) Isolation and characterization of the c-fos(ral) cDNA and analysis of posttranslational modification in vitro. Oncogene 2:79-84.

Dragunow M, Robertson GS, Faull RLM, Robertson HA, Jansen K (1990) $\mathrm{D}_{2}$ dopamine receptor antagonists induce Fos and related proteins in rat striatal neurons. Neuroscience 37:287-294.

Gerfen CR (1992) The neostriatal mosaic: multiple levels of compartmental organization. Trends Neurosci 15:133-139.

Gerfen CR, Young WS (1988) Distribution of striatonigral and striatopallidal peptidergic neurons in both patch and matrix compartments: an in situ hybridization histochemistry and fluorescent retrograde tracing study. Brain Res 460:161-167.

Gerfen CR, Engber TM, Mahan LC, Susel Z, Chase TN, Monsma FJ Jr, Sibley DR (1990) D1 and D2 dopamine receptor-regulated gene expression of striatonigral and striatopallidal neurons. Science 250: I429-1432.

Gerfen CR, McGinty JF, Young WS III (1991) Dopamine differentially regulates dynorphin, substance $\mathrm{P}$, and enkephalin expression in striatal neurons: in situ hybridization histochemical analysis. J Neurosci 11:1016-1031.

Graybiel AM, Moratalla R, Robertson HA (1990) Amphetamine and cocaine induce drug-specific activation of the c-fos gene in striosomematrix compartments and limbic subdivisions of the striatum. Proc Natl Acad Sci USA 87:6912-6916.

Hersch SM, Ciliax BJ, Gutekunst C-Y, Rees HD, Heilman CJ, Uung KKL, Bolam JP, Ince E, Yi H, Levey AI (1995) Electron microscopic analysis of D1 and D2 dopamine receptor proteins in the dorsal striatum and their synaptic relationships with motor corticostriatal afferents. J Neurosci 15:5222-5237.

Jaeger D, Kita H, Wilson CJ (1994) Surround inhibition among projection neurons is weak or nonexistent in the rat neostriatum. J Neurophysiol 72:2555-2558.

Kawaguchi Y, Wilson CJ, Emson PC (1990) Projection subtypes of rat neostriatal matrix cells revealed by intracellular injection of biocytin. J Neurosci 10:3421-3438.

Kebabian JW, Calne DB (1979) Multiple receptors for dopamine. Nature 277:93-96

Keefe K, Gerfen CR (1995) Synergistic response to combined D1- and D2-dopamine receptor stimulation in striatum; immediate early gene response to intrastriatal drug administration. Neuroscience 66:903913.

LaHoste GJ, Marshall JF (1994) Rapid development of D1 and D2 dopamine receptor supersensitivity as indicated by striatal and pallidal Fos expression. Neurosci Lett 179:153-156.

LaHoste GJ, Yu J, Marshall JF (1993) Striatal Fos expression is indicative of dopamine D1/D2 synergism and receptor supersensitivity. Proc Natl Acad Sci USA 90:7451-7455.

Le Moine C, Normand E, Guitteny AF, Fouque B, Teoule R, Bloch B (1990) Dopamine receptor gene expression by enkephalin neurons in rat forebrain. Proc Natl Acad Sci USA 87:230-234.

Le Moine C, Normand E, Bloch B (1991) Phenotypical characteriza- tion of the rat striatal neurons expressing the D1 dopamine receptor gene. Proc Natl Acad Sci USA 88:4205-4209.

Levey AI, Hersch SM, Rye DB, Sunahara RK, Niznik HB, Kitt CA, Price DL, Maggio R, Brann MR, BJ, et al. (1993) Localization of D1 and D2 dopamine receptors in brain with subtype-specific antibodies. Proc Natl Acad Sci USA 90:8861-8865.

Marshall JF, Cole BN, LaHoste GJ (1993) Dopamine D2 receptor control of pallidal fos expression: comparisons between intact and 6-hydroxydopamine-treated hemispheres. Brain Res 632:308-313

Milbrandt J (1987) A nerve growth factor-induced gene encodes a possible transcriptional regulatory factor. Science 238:797-799.

Morgan JI, Curran T (1989) Stimulus-transcription coupling in neurons: role of cellular immediate-early genes. Trends Neurosci 12:459. 462.

Paul ML, Graybiel AM, David J-C, Robertson HA (1992) D1-like and D2-like dopamine receptors synergistically activate rotation and c-fos expression in the dopamine-depleted striatum in a rat model of Parkinson's disease. J Neurosci 12:3729-3742.

Piomelli D, Pilon C, Giros B, Sokoloff P, Martres M-P, Schwartz J-C (1991) Dopamine activation of the arachidonic acid cascade as a basis for D1/D2 receptor synergism. Nature 353:164-167.

Robertson GS, Robertson HA (1986) Synergistic effects of D1 and D2 dopamine agonists on turning behavior in rats. Brain Res 384:387390.

Robertson GS, Robertson HA (1987) $D_{1}$ and $D_{2}$ dopamine agonist synergism: separate sites of action? Trends Pharmacol Sci 8:295 299.

Robertson GS, Herrera DG, Dragunow M, Robertson HA (1989) LDopa activates c-fos in the striatum ipsilateral to a 6-hydroxydopamine lesion of the substantia nigra. Eur J Pharmacol 159:99-100.

Robertson GS, Vincent SR, Fibiger HC (1992) $D_{1}$ and $D_{2}$ dopamine receptors differentially regulate c-fos expression in striatonigral and striatopallidal neurons. Neuroscience 49:285-296.

Steiner H, Gerfen CR (1993) Cocaine-induced c-fos messenger RNA is inversely related to dynorphin expression in striatum. $\mathrm{J}$ Neurosci 13:5066-5081.

Steiner H, Gerfen CR (1994) Kappa opioid receptor inhibition of D1 dopamine receptor mediated induction of immediate early genes in striatum. J Comp Neurol 353:200-212

Stoof JC, Kebabian JW (1981) Opposing roles of D-1 and D-2 dopamine receptors in efflux of cyclic AMP from rat neostriatum. Nature 294:366-368.

Surmeier DJ, Eberwine J, Wilson CJ, Cao Y, Stefani A, Kitai ST (1992) Dopamine receptor subtypes colocalize in rat striatonigral neurons. Proc Natl Acad Sci USA 89:10178-10182.

Walters JR, Bergstrom DA, Carlson JH, Chase TN, Braun AR (1987) DI dopamine receptor activation required for postsynaptic expression of D2 agonist effects. Science 236:719-722.

Weick BG, Walters JR (1987) Effects of D1 and D2 dopamine receptor stimulation on the activity of substantia nigra pars reticulata neurons in 6-hydroxydopamine lesioned rats: D1/D2 coactivation induces potentiated responses. Brain Res 405:234-246.

White FJ, Wang RY (1986) Electrophysiologic evidence for the existence of both D-1 and D-2 dopamine receptors in the nucleus accumbens. J Neurosci 6:274-280.

Wilson CJ, Groves PM (1980) Fine structure and synaptic connections of the common spiny neuron of the rat neostriatum: a study employing intracellular inject of horseradish peroxidase. J Comp Neurol 194 599-615.

Yoshikawa K, Williams C, Sabol SL (1984) Rat brain preproenkephalin mRNA. cDNA cloning, primary structure, and distribution in the nervous system. J Biol Chem 259:14301-14308.

Young ST, Porrino LJ, Iadarola MJ (1991) Cocaine induces striatal c-Fos-immunoreactive proteins via dopaminergic $\mathrm{D}_{1}$ receptors. Proc Natl Acad Sci USA 88:1291-1295. 